\title{
Benefit/risk framing (Technology Coverage)
}

\section{AUTHOR \\ Gwendolin Gurr, Julia Metag}

\section{KEYWORDS}

framing, risk-benefit-discourse, technology coverage

\section{BRIEF DESCRIPTION}

In order to identify interpretative patterns in the media coverage of technology, researches apply the variable risk and benefit framing. Risk and Benefit Framing is being measured differently; some studies use one variable, other studies use several variables to measure it. Either way, the variable is used to investigate to what extent either risks or benefits dominate the discourse and thus whether a positive or negative impression of a technology is given. In addition, it is analyzed how benefits and risks are portrayed, for example with regards to specificity and magnitude (Strekalova 2015) or how the ratio of risks and benefits changes over time or differs among different media (Donk, Metag, Kohring, \& Marcinkowski 2012).

\section{FIELD OF APPLICATION/THEORETICAL FOUNDATION}

The variable risk and benefit framing is often based on Entman's framing approach, which is frequently applied in quantitative content analyses on various topics. In media content analyses, the framing concept, however, is understood and applied differently, which is the case also for the analysis of technology coverage. In addition to risk and benefit frames, thematic or issue frames are applied including risks and/or benefits as possible frames among others (e.g. Weaver et al. 2009). Yet, some analyses are based on the assumption that a frame is a specific, unique pattern of a text composed of several elements (Kohring \& Matthes 2002; Matthes \& Kohring
2008). These elements are (a) problem definition, (b) causal attribution of responsibility, (c) moral judgment of the protagonists and their actions, and (d) treatment recommendations (Entman 1993, p. 52). Following this inductive approach, these elements are coded as single variables. After coding, frames are identified statistically by testing for relational patterns between the frame elements (Kohring \& Matthes 2002; Matthes \& Kohring 2008).

\section{REFERENCES/COMBINATION WITH OTHER METHODS OF DATA COLLECTION}

In media effects research, it can be of interest whether the frames analyzed in the media coverage are recognized by recipients and how they affect their attitudes towards a topic, which can be tested by means of surveys or experiments among recipients.

\section{EXAMPLE STUDIES:}

Strekalova (2015); Donk et al. (2012)

INFORMATION ON STREKALOVA, 2015

Authors: Yulia A. Strekalova

Research question/research interest: "How do elite and regional U.S. newspapers cover nanomedicine? How was the news about nanomedicine framed by the U.S. newspapers?"

Object of analysis: U.S. newspapers (3 national quality newspapers: The New York Times, The Washington Post, The Wall Street Journal; 3 regional newspapers: Los Angeles Times, The Boston Globe, The Houston Chronicle)

Time frame of analysis: 1990-September 30, 2013

INFORMATION ON DONK ET AL., 2012

Authors: André Donk, Julia Metag, Matthias Kohring, Frank Marcinkowski 
Research question/research interest: The framing of nanotechnology in German print media

Object of analysis: 9 German daily newspapers and weekly magazines (Financial Times Deutschland, Frankfurter Allgemeine Zeitung, Frankfurter Rundschau, Süddeutsche Zeitung, taz, Die Welt, Focus, Der Spiegel, die Zeit)
Time frame of analysis: 2000 bis 2008

Codebook: placed at disposal

\section{INFORMATION ABOUT VARIABLE}

see Table 1

Table 1.

\begin{tabular}{|c|c|c|c|c|c|}
\hline Authors & Variable name/definition & $\begin{array}{l}\text { Level of } \\
\text { analysis }\end{array}$ & Values & $\begin{array}{l}\text { Scale } \\
\text { Level }\end{array}$ & Reliability \\
\hline $\begin{array}{l}\text { Strekalova } \\
\text { (2015) }\end{array}$ & $\begin{array}{l}\text { Risk and Benefit Frames } \\
\text { (in addition: magnitude } \\
\text { and specificity of risks and } \\
\text { benefits) }\end{array}$ & article & $\begin{array}{l}\text { - } \quad \text { benefits only } \\
\text { - } \quad \text { risks only } \\
\text { benefits and } \\
\text { risks } \\
\text { - no benefits } \\
\text { or risks }\end{array}$ & nominal & $\begin{array}{l}\text { interco- } \\
\text { der relia- } \\
\text { bility: .86 } \\
\text { (range: } \\
.72-.95 \text { ) }\end{array}$ \\
\hline
\end{tabular}

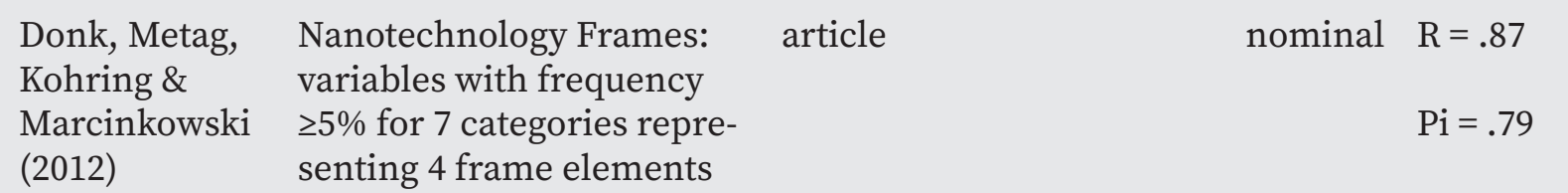

Categories for frame element "problem definition":

- Main topic

- Evaluation of benefits

- Evaluation of risks

Variables "main topic":

- Scientific research

- medical implementation

- implementation in information and communication technology (ICT)

- economy

- overview of nanotechnology

Variables "Evaluation of benefits":

- medical benefits

- scientific benefits

- economic benefits

Variables "Evaluation of risks":

- Medical risks 


\begin{tabular}{|c|c|c|c|c|}
\hline Authors & Variable name/definition & $\begin{array}{l}\text { Level of Values } \\
\text { analysis }\end{array}$ & $\begin{array}{l}\text { Scale } \\
\text { Level }\end{array}$ & Reliability \\
\hline & \multicolumn{4}{|l|}{$\begin{array}{l}\text { Categories for frame ele- } \\
\text { ment "Causal attribution of } \\
\text { responsibility": } \\
\text { - Protagonist responsible } \\
\quad \text { for benefits } \\
\text { - Protagonist responsible } \\
\quad \text { for risks }\end{array}$} \\
\hline & \multicolumn{4}{|l|}{$\begin{array}{l}\text { Variables "Protagonist re- } \\
\text { sponsible for benefits": } \\
\text { - } \quad \text { Scientist } \\
\text { - } \quad \text { economic protagonist } \\
\text { - } \quad \text { nanotechnology }\end{array}$} \\
\hline & \multicolumn{4}{|l|}{$\begin{array}{l}\text { Variables "Protagonist re- } \\
\text { sponsible for risks": } \\
\text { • Nanotechnology }\end{array}$} \\
\hline & \multicolumn{4}{|l|}{$\begin{array}{l}\text { Category for frame element } \\
\text { "Moral judgement": } \\
\text { - Evaluation of nanotechno- } \\
\text { logy }\end{array}$} \\
\hline & \multicolumn{4}{|l|}{$\begin{array}{l}\text { Variables: } \\
\text { - } \quad \text { Positive evaluation/ac- } \\
\text { ceptance } \\
\text { - } \text { negative evaluation/ac- } \\
\text { ceptance }\end{array}$} \\
\hline & \multicolumn{4}{|l|}{$\begin{array}{l}\text { Category for frame element } \\
\text { "Treatment recommenda- } \\
\text { tion": } \\
\text { - Call for regulation/sup- } \\
\quad \text { port Prospects }\end{array}$} \\
\hline & \multicolumn{4}{|l|}{$\begin{array}{l}\text { Variables: } \\
\text { - } \quad \text { Risk regulation Pro- } \\
\text { spects } \\
\text { - } \quad \text { Positive prospects }\end{array}$} \\
\hline
\end{tabular}

\section{REFERENCES}

Strekalova, Yulia A. (2015): Informing Dissemination Research. In: Science Communication 37(2), 151-172.

Donk, André; Metag, Julia; Kohring, Matthias; Marcinkowski, Frank (2012): Framing Emerging Technologies. In: Sci- ence Communication 34(1), 5-29.

\section{FURTHER REFERENCES}

Entman, R. M. (1993). Framing: Toward clarification of a fractured paradigm. Journal of Communication, 43, 5158.

Kohring, M., \& Matthes, J. (2002). The face(t)s 
of biotech in the nineties: How the German press framed modern biotechnology. Pub-

lic Understanding of Science, 11, 143154.

Matthes, J., \&, Kohring, M. (2008). The content analysis of media frames: Toward improving reliability and validity. Journal of Communication, 58, 258279. References

Weaver, D. A., Lively, E., \& Bimber, B. (2009). Searching for a Frame. Science Communication, 31(2), 139-166. 